5. Соловьев С. М. Сочинения. Москва, 1988. Кн. 2, т. 3. -345 с.

6. Спечіунас Вітовт. Стасіс Кнежис. Арвідас Гайдіс Збройні сили Великого князівства Литовського. Стаття Універсальна литовська енциклопедія 31.03.2016 Вільнюс. Електронний ресурс. Режим доступу: https://www.vle.lt/Straipsnis/Lietuvos-Didziosios-Kunigaikstystes-kariuomene-117512

7. Уривалкін О.М. Таємничі грані історії. К.: КНТ, 2007. 340 с.

8. Журавльов Д. Визначні битви та полководці української історії. Харків: Книжковий клуб «Клуб Сімейного Дозвілля», 2013. 416 с.

9. Супрасльській літопис Електронний ресурс. Режим доступу: http://litopys.org.ua/psrl3235/lytov16.htm

DOI https://doi.org/10.30525/978-9934-588-91-4-25

\title{
МАЛА ДУХОВНА СЕМІНАРІЯ У ЛЬВОВІ ЯК СКЛАДОВА БОГОСЛОВСЬКОЇ ОСВІТИ ГКЦ ВПРОДОВЖ 1920-1930-Х РР.
}

\author{
Хоркава I. I. \\ аспіранка кафедри культурології та філософії \\ Національного університету «Острозька академія» \\ м. Острог, Рівненська область, Украӥна
}

Важливим елементом організаційної структури Галицької митрополії Греко-католицької церкви (далі - ГКЦ) були духовні навчальні заклади. Вони сприяли окрім підготовки молодого покоління кліриків, ще й вихованню української молоді на засадах християнського вчення. Серед таких навчальних закладів були духовні семінарії у Львові, Станіславові та Перемишлі. Однак значимою серед них залишалася Львівська духовна семінарія, діяльність якої розпочалася ще 1783 р. Саме в її структурі діяло дві філії, так звані Малі духовні семінарії у Львові та Рогатині [1, с. 142-144]. Отже, метою даної розвідки є аналіз організаційної структури Малої духовної семінарії у Львові впродовж 1920-1930-х pp.

Мала духовна семінарія у Львові була організована ухвалою Львівського Синоду ГКЦ, який розпочав свою роботу 24 вересня 1891 p. Рішенням його учасників духовні семінарії розділялися на два типи, а саме малі та великі. У малих юнаки повинні здобувати середню освіту з обов'язковим прослуховуванням духовних вправ. Якщо за час навчання вони виявили у собі покликання до священичого стану, то після його завершення могли вступати до вищої духовної семінарії; i великі, в яких уже навчалися кандидати духовного стану [2, с. 150]. 
Офіційною назвою навчального закладу була «Мала духовна семінарія імені святого Йосафата», однак у щоденному вжитку використовувалася назва Мала духовна семінарія. Її керівником був ректор, якого призначав Митрополит ГКЦ. Він виконував свої обов'язки впродовж трьох років. Для вирішення питань організації навчальної роботи ректору допомагали духівник, в обов'язки якого входило нагляд за належним виконанням учнями духовних вправ і префект, який вирішував питання господарсько-економічного забезпечення семінарії, а також дотриманням її вихованцями дисципліни [3, арк. 2].

Впродовж 1922-1926 рр. керівником Малої духовної семінарії був I. Бучко. Однак після того, як його призначили на посаду єпископапомічника митрополита ГКЦ А. Шептицького, він змушений був скласти свої повноваження. Його замінив на цій посаді Я.-Ф. Т. Перрідон [4, арк. 33]. Як очільник семінарії він подбав про наведення ладу на території іiі подвір'я та приміщенні кімнат гігієни, розробив чіткі правила внутрішнього розпорядку для вихованців. Зауважимо, що багато власних коштів він витратив на закупівлю навчальної літератури. Із погіршенням здоров'я Я. Перрідон змушений був відмовитися від цієї посади, а 1935 р. переїхати до Голландії. Новим очільником Малої духовної семінарії став викладач Греко-католицької богословської академії у Львові Л. Глинка. На початку своєї роботи у нього склалися досить напружені стосунки з педагогічним колективом, а особливо з іiі вихованцями. Однак, згодом, відносини між ними ввійшли у належне русло [5, арк. 1-3].

Навчання у Малій духовній семінарії тривало 7 років, однак на засіданні іï педагогічної ради 14 червня 1935 р. було прийнято рішення відкрити у новому 1935-1936 навчальному році ще й 8 клас [6, арк. 3-4]. Серед обов'язкових дисциплін, які повинні були засвоїти ії вихованці були українська, польська, латинська і грецька мови, математика, фізика, історія і релігія [7, арк. 2-11].

Педагогами у ній зазвичай були ті особи, яких особисто запрошував митрополит або іiї ректор. Однак траплялися випадки, коли претенденти на посади особисто зверталися до них із відповідним проханням. Серед таких осіб були викладач фізики М. Козик та духівник І. Гнатів [8, арк. 4-5]. Серед збережених архівних документів, які містяться у Львівському державному історичному архіві, ми дізнаємося, що на 1933-1934 навчальний рік до педагогічного колективу входили викладач релігії М. Хмільовський, української мови М. Гнатишак, польської мови В. Лев, латинської мови М. Соневицький, грецької мови М. Двуліта та Є. Піджарко, історії Р. Зубик, математики 3. Зелений і Я. Капка, фізики М. Цепуха. Опікуном, тобто вихователем був П. Ісаї. Матуристами, тобто випускниками навчального закладу в 1933-1934 навчальному році стало 55 осіб. Зокрема, складаючи випускні іспити 27 червня 1934 р. добрий результат засвідчили 17 юнаків, а достатній - 38 [9, арк. 1-4]. 
На навчання до Малої духовної семінарії зараховувалися юнаки на контрактній основі. Більшість 3 них належала до родин, матеріальне становище яких дозволяло оплатити їхне навчання. Це засвідчують листи-звернення батьків у яких вони погоджуються сплачувати щомісячно визначену вартість навчання [10, арк. 3-4]. Проте серед архівних матеріалів знаходимо інформацію про те, що через скрутне матеріальне становище не всі батьки могли вчасно і вповні оплатити вартість навчання. Так, А. Пивоварів у листі до митрополита А. Шептицького просила знизити оплату за навчання для іії сина Сергія [11, арк. 9]. Розуміючи стан справ митрополит дозволяв оплачувати вартість навчання поступово невеликими сумами, оскільки розумів, що не можна залишити поза увагою тих юнаків, які через скрутне фінансове становище у сім'ї втратили б можливість здобути освіту.

Іншою категорією дітей, яка навчалася у семінарії безкоштовно були сироти. Їхнє утримання здійснювалося за рахунок Митрополичого ординаріату та коштів, які надходили від парафіяльного духовенства [10, арк. 1]. Зауважимо, що не завжди їх вистачало, оскільки дітямсиротам потрібно було придбати одяг, взуття та все інше, необхідне для їх навчання. Зауважимо, що дохід семінарії від оплати за навчання та складання іспитів станом на 1930-1931 навчальний рік становив 5080 пол. зл. Усі отримані кошти ішли на оплату праці педагогічного колективу та придбання навчального інвентарю [12, арк. 7]. Проте керівництво намагалося виходити із важкого становища залучаючи для цього місцевих благодійників. Ці кошти ішли не лише на забезпечення потреб юнаків, а також на приготування «простих поживних страв» [3, арк. 7].

Окрім навчального процесу юнаки були залучені до гурткової роботи. Зокрема, 1931 р. розпочав діяльність спортивно-виховний гурток під назвою «Гігієнічний гурток здоров'я». Його очільником був В. Гладкий, який всіляко спрямовував юнаків до здорового способу життя, активного заняття спортом та загартування власного організму [12, арк. 8]. 110 вихованців Малої духовної семінарії входило до гуртка «Відродження». Його організація, на думку керівника Т. Глушкевича, виявилася актуальною, оскільки у цей час простежувалася тенденція надмірного споживання алкоголю людьми різного вікового складу. Юнаки, під керівництвом досвідченого наставника, готували дослідження про негативний вплив алкоголю на життя людини та його наслідки для здоров'я, а також моральну деградацію суспільства [13, арк. 24].

Отже, аналіз діяльності Малої духовної семінарії у Львові впродовж 1920-1930-х pp. засвідчив, що очільники Греко-католицької церкви пильну увагу приділяли роботі їі навчальних закладів. Вектор основних дисциплін у ній спрямовувався, насамперед, на предмети гуманітарного та духовного циклу, однак не виключав природничих 
дисциплін. Крім цього, Мала духовна семінарія була тим навчальним закладом у якому мали змогу отримати середню освіту діти, які походили з бідних або середнього достатку родин. Водночас, юнаки залучалися до гурткової роботи, яка консолідувала молодих людей до активного та здорового способу життя, а також виховувала їх майбутніми вступниками до вищих духовних семінарій.

\section{Література:}

1. Пилипів I. В. Греко-католицька церква в суспільно-політичному житті Східної Галичини (1918-1939рр.). Тернопіль: Економічна думка THEУ, 2011. $440 \mathrm{c}$.

2. Пилипів І., Делятинський Р. Розвиток богословської освіти в Галицькій греко-католицькій митрополії в другій половині XIX - XX ст. Галичина: Історія релігії і церкви. С. 148-155.

3. Статути Малої духовної семінарії. Центральний державний історичний архів України, м. Львів (далі - ЦДІАЛ), ф. 451, оп. 1, спр. 367, арк. 2.

4. Листи монахинь василіанських монастирів в Дрогобичі, Львові, Яворові та ін. місцевостях ректору Галущинському Теодозію про монастирське життя і свої особові справи. ЦДІАЛ, ф. 451, оп. 2, спр. 106, арк. 33.

5. Листи ректора Малої духовної семінарії в м. Львові Глинки Лева Греко-католицькому митрополичому ординаріатові там же про спростування вміщеної його замітки в газеті «Новий час». ЦДІАЛ, ф. 451, оп. 1, спр. 374, арк. 1-3.

6. Листи Педагогічної ради Малої духовної семінарії митрополиту Шептицькому про надання дозволу на відкриття 8-го класу семінарії. ЦДІАЛ, ф. 451, оп. 1, спр. 368, арк. 3-4.

7. Листи Греко-католицького митрополичого ординаріату в м. Львові викладачам Малої духовної семінарії там же про введення їх до складу екзаменаційної комісії для прийому випускних екзаменів. ЦДІАЛ, ф. 451, оп. 1, спр. 370, арк. 2-11.

8. Заяви священиків і учителів Греко-католицькому митрополичому ординаріату в м. Львові про надання їм посади викладачів в Малій духовній семінарії там же. ЦДІАЛ, ф. 451, оп. 1, спр. 377, арк. 4-5.

9. Листування Малої духовної семінарії з Греко-католицьким митрополичим ординаріатом у м. Львові про затвердження складу екзаменаційної комісії. ЦДІАЛ, ф. 451, оп. 1, спр. 371, арк. 1-4.

10. Листи Греко-католицької Митрополичої консисторії до управління бурси ім. св. Йосафата про виділення коштів на утримання іiі вихованців. ЦДІАЛ, ф. 451, оп. 1, спр. 366, арк. 3-4.

11. Листування Греко-католицького Митрополичого ординаріату в м. Львові 3 парафіяльними управліннями, притулками для сиріт, 
товариством «Просвіта» і ін. про прийом учнів до Малої духовної семінарії. ЦДІАЛ, ф. 451, оп. 1, спр. 378, арк. 9.

12. Листування Малої духовної семінарії в м. Львові з Грекокатолицьким митрополичим ординаріатом там же про виділення грошей на господарські потреби. ЦДІАЛ, ф. 451, оп. 1, спр. 372, арк. 7-8.

13. Протоколи, звіти, листування та ін. документи про діяльність Малої духовної семінарії в м. Львові за 1938-1939 навчальний рік. ЦДІАЛ, ф. 451, оп. 1, спр. 369, арк. 24.

DOI https://doi.org/10.30525/978-9934-588-91-4-26

\title{
СТУДЕНТКИ ПОЛЬСЬКОЇ НАЦІОНАЛЬНОСТІ В КИЇВСЬКОМУ КОМЕРЦЙНОМУ ІНСТИТУТІ: МОВОЮ НЕВІДОМИХ АРХІВНИХ ДОКУМЕНТІВ
}

\author{
Чуткий А. I. \\ доктор історичних наук, доцент, \\ доцент кафедри давньої та нової історії Украӥни \\ Київського національного університету імені Тараса Шевченка \\ м. Київ, Україна
}

Національний чинник є важливою складовою, що визначає життя будь-якої держави світу та міжнародні відносини. Особливо потужним він став 3 середини XIX ст., а в європейському просторі - на сході континенту [12]. Серед них чільне місце належало й польському національно-визвольному руху, що посилився на початку XX ст. (коли поляки за словами Н. Дейвіса «стали більш польськими») і призвів до відновлення польської державності [13, с. 720-738].

Другим таким чинником є гендерний, зокрема дослідження ролі жіноцтва, що безумовно $є$ дуже важливим для повноцінного історичного дискурсу.

В цій статті я поєднав обидва ці чинники в контексті вивчення невідомого аспекту з історії польської громади України початку XX ст. здобуття польськими дівчатами вищої освіти у Київському комерційному інституті. Справа вивчається на основі матеріалів 3 архіву цього інституту, що вперше вводяться до наукового обігу.

Встановлено, що у Київському комерційному інституті поляки становили третю за чисельністю етнічну групу серед його студентів [14]. Також в інституті діяли дві організації, що об'єднували вихідців із Польщі - Варшавське земляцтво та Польський гурток [14]. 